\title{
Peripheral Matters: The emergence of legalized politics in local struggles over unauthorized immigration
}

Doris Marie Provine, Martha Luz Rojas-Wiesner, and Germán Martínez Velasco

Doris Marie Provine (contact person)

712 East Geneva Drive

Tempe, AZ 85282-3737

Marie.provine@gmail.com or Marie.provine@asu.edu

FAX: 480-965-9199

Biographical information:

Dr. Doris Marie Provine is Professor of Justice Studies emerita in the School of Social Transformation at Arizona State University. Her email address is marie.provine@asu.edu. The authors appreciate the assistance of Ms. Lucia Stavig, Sñr. Miguel Pickard, and the editors of this Special Issue, who read and critiqued earlier versions of this manuscript, and Ms. Paige Carr for her helpful research assistance.

Dr. Martha Luz Rojas-Wiesner is Investigator at El Colegio de la Frontera Sur, Chiapas, Mexico. She is a member of that university's Grupo Estudios de Género. Her email address is mrojas@ecosur.mx.

Germán Martínez Velasco is Professor/Investigator at El Colegio de la Frontera Sur, Chiapas, México. He is a member of that university's Grupo Académico de Estudios Transfronterizos. His email address is gmartine@ecosur.mx. 


\begin{abstract}
National immigration policy meets the realities of unauthorized immigration at the local level, often in ways undesired by residents, as exemplified by the dramatic rise of local anti-immigrant legislation in US states and municipalities. Scholars have studied why some states and municipalities, but not others, engage in immigration policymaking. Such research is not designed, however, to evaluate how the structure of American government facilitates and shapes local protest. To probe that issue, we compare Chiapas in Mexico and Arizona, both peripheral areas significantly affected by unauthorized immigration and national policies designed to control it. We find that the open texture of American federalism facilitates local activism, while Mexico's more centralized government does not. Activists within both states are similar, however, in deploying law creatively to critique national policy, a reminder of the growing worldwide significance of legal pluralism and legal consciousness in the politics of protest.
\end{abstract}




\section{INTRODUCTION}

We are witnessing the slow, painful, unraveling of a world order in which nation states, jealous of their sovereignty, could plausibly claim to control the right to enter and remain within the national territory. Political leaders continue to assure us that they can "secure the borders" and eliminate unauthorized immigration, but it is increasingly obvious that these are unachievable goals. Porous borders and transnational affiliations are realities of our times (Benhabib 2005). The call to put more "boots on the ground" in border areas has nevertheless become a potent political rallying cry in many nations of the world, reflecting widespread anxiety about national security and seemingly uncontrolled and uncontrollable changes in economy and society.

The nation state's inability to live up to its promises of a secure border is felt most keenly in border communities, which are crossing points for unauthorized immigrants on their way to other destinations, as well as places of temporary and permanent settlement (Rojas 2007). In the borderlands, unauthorized immigration is perceived as a local issue, with implications for public services, public safety, and the local economy. The isolation of these communities, typically far from national capitals, encourages practices suited to local circumstances and may spur resistance to outside intervention (Andreas 2001). It is worthwhile, therefore to consider how center and periphery 
communicate with each other in matters related to unauthorized immigration, and in particular, how border localities make their voices heard at the national level.

The ability of these communities to speak effectively to national policy makers depends on whether local political institutions are strong enough to formulate a coherent position and communicate it upwards. The United States is distinctive in this respect. Alexis de Tocqueville, touring the United States in the early 1800 s, noted its dense network of local institutions and elaborate system of local government. These characteristics have endured. The federal government routinely relies on local administration to carry out some policies. A recent immigration-related example is the Secure Communities Program, which requires that localities report to federal authorities all suspected unauthorized immigrants booked into local jails. The dense network of local institutions and habits of inter-level communication also facilitate the expression of local dissatisfaction with national policy. The United States may be unusual, in other words, not in its level of racialized anxiety about unauthorized immigration, but in the ability of its people, through local government, to make their concerns felt at higher levels. The effort to explain the rapid rise in local immigration-policy activism in the United States has engaged American scholars on several fronts. Some argue that local laws hostile toward unauthorized immigrants are a reaction to rapid settlement in "new destinations" (e.g. Singer, Hardwick, and Brettell 2008). Others assert the significance of Republican dominance in producing such 
legislation (Chavez and Provine 2009, Lewis, Provine, Varsanyi, and Decker 2012, Boehm 2012, Ramiksharian and Wong 2010). There is some disagreement over the extent to which local lawmaking is intended simply to supplement federal authority or to challenge it (see e.g. Wells 2004, Newton 2012, Varsanyi 2010). The role that states and municipalities play in the enforcement of immigration law under the emerging federal policy of devolution is also a matter of scholarly interest (Provine and Varsanyi 2012).

This study takes a step back from all of this research to focus on the capacity of local communities to speak back to power at the national level. Capacity requires both the availability of institutionalized channels of communication that cut across levels of government and sufficient political experience at the local level to effectively give voice to local objections. Such a project requires reaching beyond the US case. Our strategy was to choose two borderland states -- one in the US and the other in a less elaborated federal system -- and to study the trajectory of immigration-related political activism in each. Arizona in the United States and Chiapas in Mexico provide useful comparison cases because, while differing in many ways, they are similar in being on the national periphery, with high levels of immigration and a history of problematic relationships with their central governments.

Like border communities everywhere, Chiapas and Arizona feel the pushpull of national policies that seek to maintain border controls, while at the same 
time attempting to increase foreign trade and investment, attract highly skilled workers, and facilitate tourism. These contradictory national demands, along with pressure to retain a decent human-rights record in an era of growing economic inequality and desperation, are negotiated on a daily basis in borderlands. At the national level, however, the contradictions of actual border management tend to be poorly understood or completely unappreciated.

The southern borders of Mexico and the United States have taken on new significance as both nations have prioritized immigration enforcement. The first task of this article is to look more closely at this development from a local perspective. The next step is to analyze the opportunities and constraints that shape local protest directed at national decision-makers. A major constraint, of course, is the assertion by national governments of their sovereignty in matters related to immigration, an assertion that applies, not just to domestic courts and to foreign nations, but also to all governmental units under the national umbrella. The capacity of central government to control its outermost regions, however, and the degree to which it must listen to these regions, is variable over time and space, and so should be considered a matter for empirical investigation.

While our comparative case study of Arizona and Chiapas reveals significant differences in the capacity of these local communities to effectively voice opposition to national policy, there is a striking similarity in the preference of activists in each place for legalized styles of protest. This preference for law 
may be traceable in part to the fact that governance in large contemporary states encompasses multiple levels of law, creating a kind of officially sanctioned legal pluralism. Meta-national human-rights norms and institutions add to this layering, creating opportunities to challenge political decisions through law. Legalized forms of protest also attract activists because of law's normative dimension. Law inserts a moral "ought" into political protest and evokes the idea of rights, a framing that can be useful in legislative lobbying, media campaigns, and public protest (McCann 2006). In the process legal consciousness deepens and spreads, even in nations with more centralization than prevails in the United States (e.g. Chua 2012).

Immigration enforcement is a complex matter in border areas. Licit and illicit trade across national boundaries can create an insular local economy or even a "semi-autonomous social field" (Moore 1973) that resists external oversight because not all of its practices would be sanctioned by the broader legal system (Andreas 2001). Isolation from the national mainstream can also foster a sense among residents that they have been neglected and deemed unimportant (Nevins 2002). Familial and ethnic relations and residues of a pre-bordered past further complicate the local mindset. Johnson and Graybill (2010) argue for taking this perspective more seriously, recognizing the contingent nature of the nation state and the importance of sub-national histories in defining it. 
Arizona and Chiapas furnish apt exemplars, steeped as they have been in cross-border trade, work, and settlement, and operating with memories of a long pre-enforcement history. In both cases large indigenous populations settled in the area before the two nations created a legal border. For many decades, both indigenous and non-indigenous populations carried on their activities without much interference from federal authorities. Businesses depended on visitors from the other side. In Arizona during the World War I era, US authorities did try to control the border because of security concerns. Two federal statutes designed to seal the border, the Immigration Act of 1917 and the Passport Act of 1918, reflect this intention. But Kang's review of the files of federal agents stationed on the Southwest border reveals angry protests from locals and requests for exceptions that soon swamped federal strictures, re-establishing earlier patterns of border commerce and travel: "Indeed, throughout the agency's history, border residents have been some of the most vehement and persistent opponents of any regulation that threatened to encroach upon their freedom of movement across the international line" (Kang 181, 2010). Between 1910 and 1920, in the face of antitravel initiatives at the national level, 1.5 million Mexicans entered the United States (Ibid).

Local pressure in the opposing direction, to increase enforcement, requires a more overtly political strategy involving complaints to federal representatives and attention-drawing local politicking. Decisions President Clinton and 
Congress made in the 1990s furnish an example. Apparently inspired by growing anti-immigrant sentiment and political activity in California and other Southwestern states, President Clinton embraced two border-strengthening initiatives, Operation Hold the Line in El Paso, Texas, in 1993, and Operation Gatekeeper in San Diego, California, in 1994. The border's vast desert region, deemed too hostile for easy passage, was left only lightly patrolled. This approach was soon to have significant implications for Arizona, which up until that time had mostly local traffic across its southern border.

Pressure to gain more control over unauthorized immigration continued as Congress in 1996 adopted two major pieces of legislation, that, among other things, increased penalties for illegal entry, invited local participation in federal immigration enforcement, reduced immigrant rights, and attempted to reduce the "magnet" of benefits and jobs that were presumed to attract unauthorized immigrants. During this period the size and budget of the Border Patrol began to grow rapidly. (It has now quintupled, growing from about 4,000 to over 20,000 agents.)

Mexico was also feeling the effect of the U.S. job magnet in the late 1990s, and increasingly finding itself receiving immigrants from Central America, mostly bound for the United States, even as more of its own nationals migrated northward. Neither of these trends was new for Mexico, but their dimensions were for the first time drawing national and international attention. The 
September 11, 2001 terrorist attacks in New York and Washington further heightened attention to border issues in Mexico. On both the U.S. and Mexican southern borders, the presence and activities of large numbers of federal immigration-control agents soon became part of the local landscape, while at the same time increasing the vulnerability of unauthorized immigrants to every form of exploitation and criminal victimization, including abuse from over-zealous border-patrol personnel. The effects have been felt on local residents as well as migrants. In Douglas, Arizona, for example, businesses complain that the increased difficulty of crossing the border has driven away Mexican shoppers; as one remarked: "There's a lot of money being lost in the name of security" (Santos 2012a).

This history features law on all sides. The federal governments in Mexico and the United States have justified legislation supporting their increased presence on the border in legal terms, arguing that the ascertainment of legal status is crucial to promoting national security. Arizona lawmakers have taken this approach a step further, drawing new legal distinctions at the state level and designing new enforcement modalities to deflect and deter unauthorized immigrants. Pro-immigrant activists in Arizona and Chiapas also rely on law, particularly human-rights standards, to argue for changes in national policy; treaty obligations and constitutional guarantees also factor into their arguments. In Chiapas, in contrast to Arizona, local legislation has been adopted that pointedly 
overlooks legal status. All of these activities reveal belief in the capacity of law to reframe people and their role in society in fundamental ways (de Genova 2002), or in Coutin's words, to “define not only national borders, but also spaces of existence within national territories" $(2001,118)$. Arizona and Chiapas activists would agree with $\operatorname{Ngai}(2004,4)$ that it is law that makes unauthorized immigrants "impossible subjects," but they would add that law can also lend credence political arguments in the increasingly law-saturated environments in which contemporary societies operate (Hirschl 2006, Kagan 2001, Epp 2011).

\section{IMMIGRATION ACTIVISM IN ARIZONA}

The state known as Arizona was once part of Mexico. The Arizona Territory dates from the Treaty of Guadalupe Hidalgo in 1848 and the Gadsden Purchase in 1853. These treaties added a vast area to the United States, including most of present-day Arizona and also California, Utah, Nevada, and parts of New Mexico, Colorado and Wyoming. The treaties allowed Mexicans residing in the new US territories to claim American citizenship, treating Mexicans as legally "white" so as not to violate the federal law that restricted citizenship to whites. This arrangement, designed to resolve diplomatic issues between Mexico and the United States, aroused concerns among Anglos that Mexicans and indigenous residents would have too much political influence. The solution was to divide the area into two states, with New Mexico absorbing most of the non-whites.

Arizona and New Mexico became states in 1912. That same year Arizona 
adopted an English literacy test for voting. Requirements for minimum education, local property ownership and minimum periods of residency all worked to disenfranchise Mexican-American voters from influence in local politics (Perales 2013).

Arizona's early preoccupation with the presumed negative influence of Mexican-origin people became a distinctive feature of its politics. Conflicts were common as Anglos asserted dominance. Mexican-Americans worked in Arizona copper mines at less than half the Anglo wage, provoking strikes and labor unrest (Gordon 1999). The reaction to strikers was often violent. In 1917, the town of Bisbee Arizona responded to demands for better wages and working conditions from miners of mostly Mexican origin by deporting over 1,000 foreign workers and their allies. With the help of the local sheriff and deputized residents, the miners were herded into manure-laden boxcars and shipped east under armed guard into the New Mexico desert, where they were abandoned, later to be rescued by U.S. soldiers stationed in the area (Bailey 1983).

Segregation, with Mexican-Americans treated as a separate race, was legal in Arizona until 1953, when the Arizona Supreme Court declared the practice unconstitutional. Segregation had been the policy, not just in the public schools, but also at public swimming pools, parks, and churches. Neighborhoods were segregated by race, with this arrangement backed up by racially restrictive covenants in deeds. The Latino presence at the state's universities and in the 
professions was minimal in this period. Their presence in the state's agriculture, mining, construction, and service sectors, however, was large and economically important. Yet their numbers were easy to ignore because of their political disenfranchisement and lack of citizenship. In Arizona, as in the neighboring states of New Mexico and California, many whites regarded Mexican Americans as workers whose real roots lay in Mexico (Gomez 2007, Chavez 2008).

The demise of legal segregation and rising concern about civil rights and racial discrimination changed the rules, but not the belief in powerful quarters that Anglo culture must remain dominant in Arizona. During the 1960s, Operation Eagle Eye excluded many Arizona Latinos from voting. The state challenged the federal government's 1970 ban on literacy tests in court; since then it has had continual difficulties getting its redistricting plans approved as non-discriminatory against Latino voters (Perales). The state legislature made English the state's official language in 1988, but a state court declared that law unconstitutional. Immigration was not a salient issue at this time, in part because political leaders had not yet made it one, and in part because, despite some political gains, Arizona's Mexican-American residents "knew their place." Living in Arizona as an unauthorized immigrant was not difficult if one did not get into serious trouble. Even when arrests occurred, federal authorities were not always notified, and even if notified, did not necessarily act on the information they received. The border was porous, with migrants from Mexico crossing into and out of Arizona 
without much difficulty. Federal immigration officials were a minor presence in the state and conducted no raids. This situation, although it was not evident at the time, was about to change.

\section{The emergence of concerns about border security}

With Operation Gatekeeper's addition of 1000 border patrol agents in San Diego, Mexican and Central American migrants began to re-route their northward journey through the lightly patrolled Arizona desert. As this traffic grew, so did the number of border deaths caused by harsh conditions, increasing from nine in 1990 to 201 by 2005 (Rubio-Goldsmith et al., 2006). ${ }^{\text {i }}$ These developments changed the way that many Arizonans viewed unauthorized immigrants. Border crossing could no longer be viewed simply as a way for Mexican workers to come to the state on a temporary basis. The new reality was large numbers who passed through Arizona in order to reach destinations further in the interior. More migrants were also settling permanently in the state with their families because of the increasing difficulty of moving back and forth across the border. The increasingly treacherous border also increased human smuggling operations and predatory kidnapping around the Arizona border. Because of increased controls, much more money could be earned transporting migrants than had ever been true before.

These new dangers spurred the growth of already existing grassroots organizations like the American Friends Service Committee and the creation of 
new groups dedicated to preventing harm to migrants and to advocating on behalf of their rights. Border Action Network was formed in 1999. Its "Twelve Political Principles" include the right to live and work in the United States, basic human services, family reunification, and respect for immigrant contributions (BAN 2012). In 2003, religious leaders in Tucson, Arizona, which lies relatively close to the border with Mexico, began meeting out of frustration with the growing numbers of migrant deaths in the desert. Within a year they had formed No More Deaths, a human-rights organization aiding migrants with medical help and watering stations and, at a policy level, advocating for a more humane immigration policy (NMD 2012). The Kino Border Initiative, made up of religious organizations on both sides of the border, was founded in 2009 with the mission of humanitarian assistance for migrants and the transformation of local, regional, and national immigration policies.

These organizations and others like them deploy various strategies to press for change in U.S. immigration policy and Arizona law. They have co-sponsored marches of unprecedented size and conduct vigorous public-education campaigns, but a significant and growing part of their work focuses on law and rights. They investigate and document abuses that migrants suffer, framing their analyses around human rights principles and protections under American law. Their efforts include close scrutiny of state legislative proposals, formal complaints to federal officials for violations of immigrant rights, and sometimes lawsuits. 
Violations of the law by border patrol agents are a special focus of concern. Law and legality, in short, play a central role in their advocacy.

\section{The legislature crafts its protest through law}

Political leaders in Arizona have also focused on law, both as a means to gain control of unauthorized immigration and as a way to broadcast their dissatisfaction with the status quo. Arizona legislators took notice in 1994 when neighboring California enacted Proposition 187, a very popular citizens' initiative that showcased the state's resolve to deflect and discourage unauthorized immigrants by denying them essential services. Although a federal court quickly declared most of Proposition 187 unconstitutional, its passage and the publicity it generated showed how a state law could be used politically to push for more restrictive legislation at a national level, with political benefits to its proponents.

Opinion about the government in Washington, never very favorable in Arizona, was at a low point in this period. The increased flow of immigrants to and through the state had fueled a pervasive sense that Arizona's vital interests had been sacrificed to Washington politics. The failure of the federal government to fully reimburse the state's costs for imprisoning unauthorized immigrants convicted of state-level crimes was a particular sore point (McDowell and Provine 2013).

The Arizona legislature's Republican leadership, aroused to action on behalf of its mostly conservative Anglo constituent base, began to develop its own 
immigration policies. The goal at first was to discourage unauthorized immigrants from settling in the state by cutting off services and criminalizing their employment. The legislature began passing such bills in 2003, but thengovernor Janet Napolitano, a Democrat, vetoed them, arguing that immigration enforcement is solely a federal responsibility, which led her opponents to label her "the illegal-alien governor."

Governor Napolitano did sign one law in 2005 that proved to have a pronounced negative effect on unauthorized immigrants in the state. The statute was ostensibly designed to combat human smuggling, but its language was capacious enough to permit the Maricopa County prosecutor to charge immigrants as co-conspirators in their own smuggling. ${ }^{\text {ii }}$ Maricopa County Sheriff Joseph Arpaio, a recent convert to the campaign to drive out unauthorized immigrants, began aggressively to enforce this statute, and in the process became a nationally known figure. Within six weeks of the law's effective date, the Sheriff and his deputies, assisted by a 250-person posse, had made 147 arrests. In a 2006 interview on Fox News the Sheriff explained his position to a national audience: "It's a violation of the law, and I'm going to put tents up from here to Mexico if I have to, to keep these illegals incarcerated." (La Jeunesse 2006).

Republican leaders at this point sponsored a series of ballot initiatives, a favorite means of bypassing the traditional legislative process (and gubernatorial veto potential) in Arizona and many Western states. ${ }^{\text {iii }}$ This strategy worked 
(Sinema 2012). In 2006 -- against the advice of the governor, mayors in major metropolitan areas, and Arizona's entire Congressional delegation -- large majorities of citizens voted to deny college students without legal status the benefit of in-state tuition rates at state universities. Initiatives that year also denied unauthorized immigrants access to state welfare services, including adult English-language classes, and access to bail in serious criminal cases. Voters made English the state's official language, to be given priority in all stategovernment communication.

The perceived inability of Congress to agree upon comprehensive immigration reform made Governor Napolitano's hands-off position increasingly untenable. By 2007, she was persuaded to sign a bill penalizing employers who knowingly hire unauthorized workers with loss of their state-issued business licenses. The U.S. Supreme Court upheld the Legal Arizona Workers Act in May 2011. ${ }^{\text {iv }}$ Despite its ostensible focus on employers, Arizona's sanctions have been limited almost entirely to immigrant workers, with only minor disruptions for two businesses, one of which was already in bankruptcy proceedings. Plascencia's study of the 55 "operations" conducted under this law concludes that enforcement was never aimed at businesses, but rather 'the 'force of law' appears to be ultimately aimed principally at disciplining migrants without employment authorization" (2012). 
The next step was to bring federal immigration law into the realm of ordinary law enforcement. Congress had encouraged partnerships with federal immigration agents in the 1996 Illegal Immigration Reform and Immigrant Responsibility Act, which offered training to prepare local law-enforcement officers to assist in immigration enforcement. The law attracted little interest for most of its first decade, but in 2006 Sheriff Arpaio arranged for sixty deputies to receive training. Soon his deputies began to arrest scores of unauthorized immigrants, sometimes by raiding their places of employment. Maricopa County became a national leader in the number of deportations arising from arrests by local law-enforcement officers.

The sheriff's raids became notorious, particularly after one of them occurred without warning at midnight in a municipal library in Mesa, Arizona, a city that had decided against aggressive immigration enforcement. The resulting controversy and persistent complaints about racial profiling and excesses in other raids eventually forced the federal government to revoke the agreement it had signed with Sheriff Arpaio, but by then the state legislature had prepared its own legislation authorizing immigration arrests by local police. The announced goal of the 2010 law, known as SB1070, was "attrition through enforcement," to be achieved through a potpourri of provisions, all directed toward the removal of unauthorized immigrants from the state. Most controversially, local police gained authority to inquire about immigration status in any stop if the officer suspected 
that the person might not have legal status. Failure to implement this policy to the fullest exposed the law-enforcement agency to civil suit by any Arizona citizen.

SB1070 was immediately controversial because of the obvious likelihood of pretextual stops and racial profiling. The surge of protest locally, nationally, and even internationally dramatically expanded the visibility of Arizona as a site of struggle over immigration, and exposed the state to boycotts protesting the legislation. Seven lawsuits were filed to overturn the law, including one by the federal government. In July 2012 the US Supreme Court declared that three sections interfered with federal immigration law, but the Court let stand, at least temporarily, the section allowing local officers to question immigration status in the course of a stop or arrest. In February 2013 researchers at Syracuse University reported that Arpaio’s Maricopa County jail had more immigrants with federal detainers than any other facility in the nation, including much larger cities like Los Angeles with far larger immigrant populations (TRAC 2013).

SB1070 was, in a sense, the capstone of the Arizona legislature's effort to craft its own immigration-control program. The goals were practical, but also political, the object being to nudge the federal government toward restrictive action by showing that an enforcement-only approach is feasible and popular with voters. For a time, SB1070's popularity, and look-alike statutes in several other states seemed to dampen talk at the national level of a path toward citizenship for immigrants without legal status. In Arizona it bolstered the fortunes of 
Republicans running for re-election. Alfredo Gutierrez, a former state senator and radio host, describes the attitude among immigrants in the state after the 2010 electoral victories: "The excitement of four years ago has turned into bitterness; hope has turned into fear" (Santos 2012).

Fear continues to saturate relationships between Latinos and state officials, particularly law enforcement. There are, however, signs of change brought about by the growing power of the Latino vote and political organizing to mobilize this constituency. The president of the state senate, one of the most virulent and powerful opponents of unauthorized immigrants, lost his position in 2011 through a recall election led by Latinos and supported by business and some elements within the Mormon church. At about the same time the county attorney who had led the effort to prosecute smuggled immigrants was disbarred.

More generally, there appears to be a growing sense that Arizona's harsh approach to its estimated 400,000 unauthorized residents is harmful to business and a liability for office-holders. Bills directly attacking the lives of unauthorized residents were absent from the 2013 legislative session, though the legislature did adopt two laws aimed at reducing the impact of organizations focused on increasing the Latino vote. Legally imbued politics remains the preferred strategy for advocates on all sides of the Arizona immigration debate.

\section{IMMIGRATION ACTIVISM IN CHIAPAS}


The current border between Mexico and Guatemala -- over 600 miles long -- was not established until 1882, when the two nations signed the Treaty of Limits. The border with Belize makes up the remainder of the 713-mile southern edge of Mexico. The entire region has a large indigenous Mayan-speaking population, which helps to explain the area's long history of cross-border trade and travel and a sense of distance from the Mexican state, which has never offered indigenous residents the full benefits of citizenship (Colby \& Den Berghe 1961, Cruz Burguete 1998). For this population, Castillo argues, “international borders are something far from their daily dynamics and are therefore a meaningless obstacle" to the maintenance of cross-border ties $(2003,37)$. At present, Chiapas has a population of 4.7 million inhabitants, 27 percent of whom speak a Mesoamerican or related language. Chiapas and the other eleven states in central, south, and southeast Mexico contain 90 percent of the nation's entire indigenous population (INEGI 2010).

From early in its establishment as Mexican territory, Chiapas attracted white settlers interested in agriculture and coffee growing, including immigrants from Germany and other parts of Europe (Mahnken 1993). By mid-twentieth century, cattle ranching had begun to overtake the smaller farms. Class and race relations grew harsher. The few thousand ranching families that owned half the state forced the Indians off the land, leaving them to work as laborers on coffee fincas or as hourly-wage workers. Around 1960, many of them departed for the 
Lacandon Jungle, in the rain forest. After several decades there, they began to organize politically to demand their rights. The abuse and impoverishment that they had endured, as well as the national government's decision to change the national constitution to reduce communal land ownership, precipitated armed conflict in 1994. The Zapatista rebels fought, not just to end discrimination against the indigenous population, but also to draw attention to the implications of neo-liberal policies promoting free trade and unrestricted development. Hostilities broke out, not coincidentally, on the day that Mexico signed the North American Free Trade Agreement (Collins 2010).

The Mexican government responded to the Zapatista uprising with military force and harassment of peasant groups, not with financial aid. Chiapas, despite its rich supplies of hydroelectric power and large forests, remains Mexico's poorest state with a poverty rate of 75.5 percent (Johnson 2008). Over half of the population lives in communities of 2,500 people or fewer. Severe hurricanes and flooding have also taken a toll on the area. As one local resident observed: "It's not true that Chiapas is poor. Chiapas is rich in natural resources. It's the people of Chiapas who are poor" (Farmer 1998, 14).

In the 1980s neighboring Guatemala became embroiled in a US-backed civil war and the military began to viciously attack indigenous populations, who were believed to be sympathetic to the guerillas and to communism. Over 100,000 people were killed in the conflict and over one million people were 
driven into exile or displaced, an estimated 200,000 of whom fled into southern Mexico (Castillo 2006). These refugees changed Chiapas, both demographically and economically. The local economy boomed with international aid funding and the Guatemalan presence in the state became more substantial. About 22,000 Guatemalans remained, many becoming naturalized citizens.

As in the United States, the southern border of Mexico was for a long time completely unregulated, in part to facilitate cross-border trade, family connections, and a large seasonal influx of between 45,000 and 75,000 Guatemalan agricultural and domestic workers (Castillo 2006). There are eight official crossing points along this border, but over 1,000 blind spots in the mountainous terrain, only 44 of which are accessible by vehicle. Some parts of the border are covered with dense jungle. As two reporters who traveled 500 miles of border roads in 2011 observed: "for the indigenous peoples, ranch hands and smugglers who traverse it freely, there is no border at all. It is a line on the map" (Miroff and Booth 2011).

\section{The emergence of concerns about border security}

Mexico's national government, at US urging, now attempts to differentiate between migrants whose labor contributes to the national economy and those simply passing through or bent on criminal activities. In the 1990s Mexico liberalized access to business, visitors, investors and seasonal workers, but tightened access to visas for Central Americans seeking to move beyond the southern border area. At the national level, Chiapas was beginning to be seen, not 
just as a venue for cross-border commerce and a way station in the northward migration of workers, but as a virtually unguarded entry point into the country. In 1998 the government announced a plan to seal the southern border in order to control crime and US-bound migration. Checkpoints were established along highways heading north. To avoid detection, migrants began to ride atop northbound freight trains and to cross via remote roads. Isolated from public view, they became much more vulnerable to assault and robbery by criminal gangs and to extortion by corrupt officials.

The Mexican government was caught in a difficult position. Criticized for the injuries, deaths, and assaults that migrants suffered in its territory, it was at the same time feeling pressure from the United States to increase security. For President Fox, however, the southern border was primarily a bargaining chip in his effort to improve the legal status of Mexicans already settled in the United States. Negotiations between presidents Fox and Bush resulted in the June 2001 introduction of Plan Sur, a border-fortification project supported in part by US funds. Within fifteen days, 6,000 people had been deported from Mexico (Kovic and Kelly 2005). The number of deportations had begun to grow even before that point, however. Castillo (2006) reports that deportations, mostly of Guatemalans, had steadily increased each year beginning in the 1990s, reaching 200,000 by 2005. Plan Sur included funds for Grupos Beta, a program that placed a small number of immigration agents in border areas to assist migrants in distress. At 
about the same time Mexico entered into a separate pilot repatriation plan with Guatemala. $^{\text {vi }}$

The September 11, 2001 terrorist attacks added to concerns about the porosity of the southern border; that year Mexico deported 147,000 unauthorized immigrants, nearly all Central Americans who had come through Chiapas. As The Economist reported in a 2004 article: "The area is seen by American and Mexican officials as a new frontier in the war against terror. Fresh resources have gone into policing it" (Economist 2004). Additional border-control plans were adopted in 2005, including a plan to repatriate Salvadoran migrants. ${ }^{v}$ The national migration agency, Instituto Nacional de Migracion (INM) was incorporated into the internal security apparatus in 2005, emulating the Homeland Security model in the US. (Johnson 2008: 16).

$$
\text { Gradually -- and with US encouragement and financial support -- Mexico }
$$
was developing an immigration-enforcement policy focusing on apprehension, detention, and expedited deportation of unauthorized immigrants. In 2007, Mexico accepted American funds under the Merida Initiative, a $\$ 1.6$ billion package that included $\$ 400$ million in military and police equipment and training. The number of detention centers doubled between 2000 and 2011 (Alba and Castillo 2012). In the wave of concern about national security, human rights and protection of migrants were pushed into the background. As one observer 
complained: "Political negotiations for the Merida Initiative have neutered clauses designed to protect human rights" (Inkpen 2012).

Most of the Mexican federal government's immigration-control programs have focused on Chiapas and migration by Central Americans. Of those migrants detained by federal authorities, 95 percent come from Central America. Detention centers are also concentrated in Chiapas, particularly in Tapachula, which has the nation's largest, with 960 beds (Diaz and Kuhner 2008). Many of those detained further north are brought to Tapachula in order to board up to fifteen buses bound each day for Guatemala. Two or three 35-person buses go daily to Honduras.

For immigrants seeking to make their way through Mexico, the most serious problem, aside from attacks by criminal gangs, is the likelihood of extortion from municipal officials falsely claiming authority to enforce immigration law (Rojas 2008). The law clearly states that INM personnel are the only agents authorized to enforce immigration law, except in special circumstances, but this limitation is widely ignored, creating opportunities for municipal, state, and military police, fire department personnel, and even private security agents working at places like Sam's Club to demand money or sexual favors. Extortion and bribes (la mordida) are deeply rooted in Mexico, in part because municipal police are very poorly paid and not very professional, averaging a 6th grade education. The official in charge of the local office of the 
International Organization for Migration stationed in Tapachula complained of daily stops from local authorities based, he thought, on his Guatemalan license plates. He wore his identification on a retractable chain around his neck to prevent police from keeping his papers (Flores 2008).

The federal government has been ineffective in responding to problems of corruption within its own ranks or among local police. It has instead opted to increase the number of federal border agents and has provided them with broad discretion to hold migrants and deny visits from family members. Nor has government taken effective steps to reduce other hazards. The freight railway through Chiapas, known variously as "The Beast" or "The Death Express" causes many injuries and deaths when migrants attempt to board it on their journey north. Drug and contraband trafficking in the area continue to weaken local government through corruption and bribes. Human trafficking and smuggling and gang violence directed against migrants are also rampant, with (Inkpen 2012). Some of these problems could be diminished with more effective law enforcement, yet as of 2011 only about $\$ 20$ million of the $\$ 1.6$ billion Plan Merida aid package had been assigned to security for the southern border.

Shocking attacks against migrants in 2010 and 2011 by organized crime groups finally made immigration reform a top priority in the national Congress. In April 2011 the Mexican legislature unanimously approved a comprehensive law that de-criminalized migration and facilitates movement of people across the 
country. A month later President Calderon signed the legislation, citing the demand for immigrant labor and the goals of family unification and equal treatment of all residents.

Regulations for the new law have been drafted, but still not fully implemented at the local level. Some observers doubt that, even when the necessary procedures are announced, they will have much impact because of corruption within the INM, rampant crime, and other challenges (Castillo 2011). In the words of Atilano Moreno, leader of a rural communal village hugging the border with Guatemala: "There are two powers here: the soldiers and the criminals. We're caught between them" (Miroff and Booth 2011).

One observer describes Mexico's responses to the challenges of unauthorized migration as evolving, but often "reactive, uncoordinated, and sometimes contradictory" (MPI 2011). Thus Mexico encourages immigrants to regularize their status, but makes the process complicated and costly. Fees can be reduced upon a showing of poverty, but passports now are required, increasing the cost of the process. The new immigration law embraces family reunification as a goal of immigration policy, but requires a job offer in Mexico and does not necessarily recognize having a spouse or child who is a Mexican citizen as sufficient evidence of attachment. Children born in Mexico are supposed to become citizens automatically, but some judges reportedly refuse to sign birth certificates of babies born of unauthorized immigrants. The INM must approve 
marriages with a foreigner, and makes it almost impossible for anyone who has been picked up by the police to get regularized. A legal immigrant must renew his or her permiso yearly and be sure to inform the INM of any job changes, departures from the country, or change in marital or familial status. Since 2008, visas for local visitors and local temporary workers have been available in Chiapas and neighboring states, but the government has done little to prevent local authorities from continuing to harass immigrants. The temporary workers based in Chiapas tend to be poor, mostly male, and young, often working on farms or in construction or selling goods on city streets; over a fifth cannot read or write and have no schooling (Cruz 2011). Rojas reports that immigrants without documentation who have settled in Mexico fear of contact with authorities and are largely unaware of the INM's regularization program (Rojas 2011).

\section{Migrant advocates craft their protest through (human rights) law}

Alba and Castillo describe Mexican civil-society groups as playing a powerful role in advocating for migrants, often providing humanitarian assistance and legal services to detained migrants. This is a relatively new development brought about, they suggest, by the influx of refugees from Central America during the 1980s $(2012,7)$. Still, some of the problems appear intractable, including extortion by municipal and state-level police, fostered by a long tradition of personalismo, and drug-related crime and trafficking. The INM is widely viewed as corrupt. Underinvestment in the region keeps Chiapas poor and 
vulnerable to abuses. In the words of one protester: "This frontier is a forgotten place, a little hell of violence, illegality, and corrupt institutions that permit this..." (Todo por Ellos 2012).

Public opinion is not on the side of migrants. Despite their willingness to hire them for domestic service and agricultural work at rock-bottom rates, attitudes in the Chiapas area are consistent with those across the nation, with nearly half of the Mexican population opposing immigration (2010). The treatment of migrants has nevertheless attracted protests in Chiapas, including a 1997 hunger strike and a number of formal complaints of harsh security measures. In 2012, activists held an eight-day demonstration in Tapachula, including a hunger strike, to draw attention to the abuses and corruption among federal immigration officials stationed in the area. A group of local organizations has formed an immigration policy working-group (El Grupo de Trabajo sobre Politica Migratoria) that includes the Fray Matias de Córdova Human Rights Center (El Centro de Derechos Humanos Fray Matías), an immigrant-assisting organization with long roots in the area. Various organizations in San Cristóbal de Las Casas are promoting the creation of bi-national networks of civil society organizations to push Mexico toward compliance with its international obligations toward migrants.

These groups are critical of the new immigration law and its continued focus on migration as a national security issue. The law gives the Secretary of 
Public Security a significant role in enforcement, permits warrantless searches, and provides enforcement officials with virtually unlimited discretion. In effect, these groups complain, nothing has changed. Periods of detention are growing longer and migrants continue to be seen as a threat, with the law putting more residents than ever into an irregular status.

The Mexican government has not been entirely deaf to human-rights concerns. In 2002, in response to pressure to improve its human-rights record, it established an independent agency to respond to human-rights violations, Comision Nacional de Derechos Humanos (National Human Rights Commission or CNDH). The Commission's office in Tapachula investigated 336 cases in its first six years of operation, taking up many of the complaints gathered by the Fray Matias de Córdova Human Rights Center (Beltran 2008). Members of the local CNDH office visit the Tapachula detention center every day to take complaints and check on conditions. The Commission established a new special inspector general in 2005 and has gotten some improvements from INM authorities. It also seeks to advise migrants of the dangers they face in crossing Mexican national territory and offers recommendations to the Chiapas government as well as to federal authorities (García 2008, Alba and Castillo 2012).

The record of the government of Chiapas is mixed. The state's law enforcement officials continue to extort money and favors from migrants, but the state legislature has taken some positive actions. Chiapas adopted an anti- 
discrimination law to protect the rights of the immigrant population. In 2007, Chiapas revised its civil code to permit the registration of children born in Chiapas without distinction as to the migratory status of their parents. To pursue those who commit crimes against migrants, the state government created a special prosecutor. In these respects Chiapas is outpacing the federal government and, in a small way, pushing back against its laissez-faire policies.

Appeals to legality have figured prominently in all of these efforts. Legality as an organizing principle and justification figures significantly even in some extra-legal institutions, including the unofficial crossing points, or cadenas that some communities on the border have developed. Tolls collected in this manner can amount to as much as $\$ 60,000$ per year Meyers-Galemba reports. Locals pride themselves on their honesty and transparency, noting that they offer fair value (road maintenance) for the toll, in contrast with corruption and extortion at the hands of official border agents. As one observed: "There is law here" (Meyers-Galemba 2012, 7).

\section{FROM PERIPHERY TO CENTER: SPEAKING UP THROUGH LAW}

The growing power of national governments to intervene in local affairs in the name of sovereignty and security is particularly evident in border areas, but so are certain limits arising out of local desires to restore a fluid transnationalism. The economic, social, and cultural value of easy flows across borders has not diminished with time, and has perhaps increased with globalization. The stark 
territorial reality of borders, however, traps thinking and obscure the fundamental question we should be asking (Agnew 2008, 176, 187): What do borders do to people and for people? I suggest that we should also be asking how borderlands residents manage the challenges thrust upon them by their national governments.

In both Chiapas and Arizona, as we have seen, the contemporary response to national immigration policies arises out of a deep reservoir of discontent with past treatment by the national government. Nor has either area benefitted from the current emphasis on securitization, with its inevitable accompaniments of increased border-related crime, drug running, corruption, and oppressive policing. Both local economies have also suffered as controls have been tightened.

Arizona and Chiapas are responding with legalized politics and protest, albeit with very different goals in mind, as we have seen. For activists in Chiapas, the biggest obstacle is their government's inability to operate within the parameters of law. The struggle in Arizona is over whose law will prevail, the contenders being municipal, state, federal, and international human-rights law. The availability of law on every side of the debate over border policy signifies, not just the flexibility of law, but also its plurality and our reliance upon it to justify behavior. It should not be surprising, therefore, that there is widespread public anxiety over those who "take the law into their own hands" by entering national territory without permission. 
Law, of course, does not operate without context. The structure of the nation state determines, to a significant extent, the capacity of the local level to speak loudly, and sometimes persuasively, to higher authorities. In Mexico this capacity is constrained by reluctance to devolve authority and financial resources to the nation's 32 states. Despite President Vincent Fox's campaign pledge to empower the states, basic reforms have been few, hampered by the tradition of centralized governance and fear that long-standing problems of government corruption would multiply with dispersed authority (Merchant 2003, Emmond 2007). It was not even clear until the 1995 federal constitutional revision that Mexico's courts have the power to resolve conflicts between federal and state legislation (Emmond 2007: 662). Nor do voters in Mexico, in sharp contrast with many states in the United States, have the capacity to exercise grass-roots leadership through local initiatives or referenda. Chiapas, with its pervasive poverty in the face of environmental riches that have greatly benefited the nation as a whole, offers a particularly poignant example of the incapacity of local residents to be heard at the national level.

The situation in Arizona could hardly be more different. American federalism, growing out of a confederation of states, constrains the national level and reserves some powers to the states. Judicial review has been available since the earliest years of the Republic to sort out conflicts over state v. national authority. This is a recipe for a contentious political system, and that is what has 
prevailed since the nation's inception, with the Supreme Court considering federalism disputes on a regular basis.

Arizona has, from its earliest years, taken full advantage of this situation by passing non-conforming legislation and by suing to contest the federal government's power to impose air pollution standards, voting requirements, school diversity policy, and most recently, health-insurance requirements. The 2013 legislative session included a proposal to refuse to abide by any federal policy the state legislature does not like. Arizona's effort to reshape national immigration policy is consistent with this approach, justified by the theory of "dual federalism," under which states and the U.S. government operate as two sovereigns with occasionally overlapping jurisdiction.

Non-governmental organizations in Arizona also have advantages not available to similar organizations in Chiapas. A long tradition of socialmovement activity and the availability of out-of-state support facilitate their activism. The state's harsh approach toward unauthorized immigrants has energized these efforts. Still, the state government has an easier time getting national attention because of its ability to enact laws like SB1070. The Arizona case is a reminder that the capacity of localities to "speak back" to federal power with their own legislation does not always work in favor of progressive change. As Varsanyi has pointed out, neo-liberal national policies may provoke an even more regressive reaction at the local level, illustrating her point with Hazelton 
Pennsylvania's law requiring legal status to work and live in the city (2010). Immigration policy is ripe for challenge from below because, while the plenary power of the national government has been clearly established by the courts, the effects of immigration policy are mostly felt at the local level.

If Arizona's goal was, not to replace federal law, but to move the national conversation toward a more restrictive direction, it has succeeded, at least temporarily. Consider this statement by the eight U.S. senators who in January 2013 proposed to revise federal immigration law. In it they deferred to the judgment of Arizona and other Southwest-border states:

We recognize that Americans living along the Southwest border are key to recognizing and understanding when the border is truly secure. Our legislation will create a commission comprised of governors, attorneys general, and community leaders living along the Southwest border to monitor the progress of securing our border and to make a recommendation regarding when the bill's security measures outlined in the legislation are completed (Fabian 2013).

In the always-controversial realm of immigration policy, this pattern of deference at the margins and control at the center is likely become the new securitization norm. For example, the increasing devolution of enforcement authority to the local level, as epitomized by the federal rollout of the Secure Communities program, actually enhances federal discretion over deportation. 
Similarly in Chiapas, the decision to allow the cadenas to admit border crossers on their own terms enhances the impression of federal control by calming local protest and helping to make the official crossing points look more effective. Nation states have never enjoyed as much power to control borders as they have claimed, but it is important to maintain that illusion. The legalized politics around the border must contend with that reality.

\section{REFERENCES}

Agnew, John. 2008. Borders on the mind: re-framing border thinking. Ethics \& Global Politics, 1 (4): 175-191.

Alba, Francisco and Manuel Ángel Castillo. 2012. New Approaches to Migration Management in Mexico and Central America. Woodrow Wilson International Center for Scholars.

Andreas, Peter. 2000. Border Games: Policing the U.S.-Mexico Divide. Ithaca, NY: Cornell University Press.

Bailey, Lynn. 1983. Bisbee, Queen of the Copper Camps. Tucson, AZ: Westernlore Press.

Ballinas, Victor. 1999. Notes on the Economy in Chiapas in 1999. http://flag.blackened.Net/revolt/mexico/reports/chiapas_econ_99.html [retrieved $5 / 19 / 12]$

Beltran Santana, Salvador. 2005. Personal interview, Tapachula Mexico. 
Benhabib, Seyla. 2005. The Rights of Others: Aliens, Residents and Citizens. Cambridge, UK: Cambridge University Press.

Bentley, Linda. 2012. Recalling Judges, a Sticking Point for Arizona's Statehood. Sonoran News, Feb. 15, http://www.sonorannews.com/archives/2012/120215/frontpage-recalling.html (accessed May 17, 2012).

Boehm, Deborah. 2012. Intimate Migrations: Gender, Family, and Illegality Among Transnational Mexicans. New York: NYU Press.

Border Action Network (BAN). Twelve Political Principles.” http://www.borderaction.org/web/index.php?option=com_content\&view=article\&

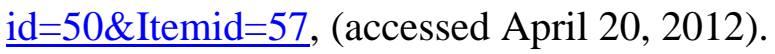

Castillo, Manuel Ángel. 2003. Mexico-Guatemala Border: New Controls on Transborder Migrations in View of Recent Integration Schemes? Frontera Norte, 15 (029): 3565.

(2005). Actores y Politicas en Torno a la Migracion en la Frontera Sur de Mexico. In Chiapas: Frontera en Movimiento, Diana Gullen (ed.), Mexico City: Instituto Mora. (2006). Mexico: Caught between the United States and Central America. Migration Information Source, April 1, 2006. (2011). Caught Between Two Migration Realities, Mexico Passes New Immigration Legislation. Migration Information Source, December 1, 2011. 
Chavez, Jorge M., and D.M. Provine. 2009. Race and the Response of State Legislatures to Unauthorized Immigrants. Annals of the American Academy of Political and Social Science 92: 623-78.

Chavez, Leo R. 2008. The Latino Threat: Constructing Immigrants, Citizens, and the Nation. Stanford, CA: Stanford University Press.

Chua, Lynette J. 2012. Pragmatic Resistance, Law, and Social Movements in Authoritarian States: The Case of Gay Collective Action in Singapore. Law \& Society Review 46(4): 713-48.

Colby, Benjamin, and Den Berghe, Pierre Van. 1961. Ethnic Relations in Southeastern Mexico. American Anthropologist 63(4): 772-92.

Collins, Stephen. 2010. Indigenous Rights and Internal Wars: The Chiapas Conflict at 15 years. The Social Science Journal 47:733-88.

Coutin, Susan. 2001. Cause Lawyering in the Shadow of the State: A US Immigration Example. In Cause Lawyering and the State in a Global Era, ed. Austin Sarat and Stuart Scheingold, 117-140, New York: Oxford.

Cruz Burguete, Jorge Luis. 1998. Identidades en Fronteras, Fronteras de Identidad. Elogio de la Intensidad de los Tiempos en los Pueblos de la Frontera Sur. Mexico City: Centro de Estudios Sociológicos, El Colegio de México.

Cruz, Hugo Ángeles. 2011. Flujos Laborales de Guatemala a la Frontera de Chiapas. Ecofronteras, 41 (enero-abril): 8 - 11. 
De Genova, Nicholas. 2010. Theoretical Overview. In The Deportation Regime:

Sovereignty, Space, and the Freedom of Movement, ed. De Genova and Peutz, Durham, NC: Duke University Press.

Eagly, Ingrid. 2011. Local Immigration Prosecution: A Study of Arizona Before SB1070. UCLA Law Review 58: 1749-1817.

Economist. 2004. The Kamikazes of Poverty. Jan. 31, Issue 8360, 33-34.

Emmond, Kenneth. 2007. Is Mexico Ready for Federalism? Mexidatainfo. January 22. http://mexidata.info/id1217.html (accessed March 4, 2013).

Epp, Charles. 2011. Making Rights Real: Activists, Bureaucrats, and the Creation of the Legalist State. Chicago, IL: University of Chicago Press.

Fabian, Jordan. 2013. Transcript: Bipartisan Framework for Comprehensive Immigration Reform. $A B C$ News, http://abcnews.go.com/ABC_Univision/News/transcriptbipartisan-framework-comprehensive-immigration-reform/story?id=18330912 (accessed March 4, 2013).

Farmer, Paul. 1998. A Visit to Chiapas. America, 178 (10): 14-18.

Figueroa, Jorge. 2008. Personal interview, Tapachula, Mexico.

Flores, Luis Eduardo. 2008. Personal interview, Tapachula, Mexico.

García, Héctor Pérez. 2008. Personal interview, Tapachula, Mexico.

Gomez, Laura E. 2007. Manifest Destinies: The Making of the Mexican American Race. NY: New York University Press. 
Gordon, Linda. 1999. The Great Arizona Orphan Abduction. Cambridge, MA: Harvard University Press.

Hensley, J.J. 2013. County Jail Leads US in ICE Holds. The Arizona Republic. B-1.

Hirschl, Ran. 2006. The New Constitution and the Judicialization of Pure Politics Worldwide. Fordham Law Review 75 (2): 721-53.

INEGI (Instituto Nacional de Estadística y Geografía) (2010). Tabulados Básicos, Censo de Población y Vivienda 2010. http://www.inegi.org.mx/est/contenidos/proyectos/ccpv/cpv2010/Default.aspx (accesed December 16, 2012).

Inkpen, Christopher. 2012. Security and Human Rights Issues on the Guatemalan/Mexican Border. Center for Strategic and International Studies. http://csis.org/blog/security-and-human-rights-issues-guatemalanmexican-borderchris-inkpen (accessed May 20, 2012).

Johnson, Benjamin J. and Andrew R. Graybill. 2010. Bridging National Borders in North America. Durham, NC: Duke University Press.

Kagan, Robert. 2001. Adversarial Legalism: The American Way of Law. Cambridge, MA: Harvard University Press.

Kang, S. Deborah. 2010. Crossing the Line: The INS and the Federal Regulation of the Mexican Border. In Benjamin Johnson and Andrew R. Graybill. Bridging National Borders in North America. Durham, NC: Duke University Press. 
Kovac, Christine and Patty Kelly. 2005. 'A Just Cause': Central American Migrants and Mexico's Southern Border. Houston Catholic Worker 15(6): 1-5.

La Jeunesse, William. 2006. Arizona Sheriff Uses Anti-Smuggling Law to Target Illegal Immigrants. Fox News, http://www.foxnews.com/story/0,2933,195083,00.html (accessed April 20, 2012).

Lewis, Paul G, D.M. Provine, M.W. Varsanyi, and S.H. Decker. 2012. Why Do (some) City Police Departments Enforce Federal Immigration Law? Political, Demographic, and Organizational Influences on Local Choices. Journal of Public Administration Research and Theory 23(1): 1-25.

López, René A., Elio Henríquez, and Fernando Camacho. 2012. Piden ONG Destituir al Comisionado del INM por el Violento Desaljo de Guatemaltecos. La Jornada http://www.jornada.unam.mx (accessed April 15, 2012).

Mahnken, Winifred. 1993. Mi Vida en los Cafetales: Tapachula (1882-1992). Gobierno del Estado de Chiapas.

McCann, Michael. 2006. Law and Social Movements. Annual Review of Law and Social Science. 2 (Fall): 17-38.

Merchant, David. 2003. Prospects for Mexican Federalism. Policy Studies Journal 31(4): 661-66.

Meyers-Galemba, Rebecca B. 2013. Making their Own Customs: Contraband and Community Border Control on the Mexico-Guatemala Border. Unpublished paper. 
Miroff, Nick and William Booth. 2011. In Southern Mexico, a Neglected Frontier. The Washington Post, June 21. http://www.washingtonpost.com/world/americas/insouthern-mexico-a-neglected-frontier/2011/06/20/AGt74KeH_story.html (accessed May 20, 2012).

Moore, Sally Falk. 1973. Law and Social Change: The Semi-autonomous Social Field as an Appropriate Subject of Study. Law \& Society Review 7 (4): 719-46.

MPI (Migration Policy Institute). 2011. Caught Between Two Migration Realities, Mexico Passes New Immigration Legislation” Issue \#10, December 1. http://www.migrationinformation.org/Feature/print.cfm?ID=871 (accessed May 21, 2012).

Nevins, J. 2002. Operation Gatekeeper and Beyond: The War on "Illegals" and the Remaking of the U.S. - Mexico Boundary. New York: Routledge.

Newton, Lina. 2012. Policy Innovation or Vertical Integration? A View of Immigration Federalism from the States. Law \& Policy 34 (1): 113-37.

Ngai, Mae M. 2004. Impossible Subjects: Illegal Aliens and the Making of Modern America. Princeton, NJ: Princeton University Press.

No More Deaths (NMD). 2012. History and Mission of No More Deaths. http://www.nomoredeaths.org/Information/history-and-mission-of-no-moredeaths.html (accessed April 20, 2012).

Perales, Nina. 2013. Shelby County v. Holder: Latino Voters Need Section 5 More Than Ever. SCOTUSblog. http://www.scotusblog.com/2013/02/shelby-county-v- 
holder-latino-voters-need-section-5-today-more-than-ever/ (accessed March 3, 2013).

Plascencia, Luis F.B. 2012. Inclusion Through Exclusion: Arizona's Employer Sanctions Law (2008-2012). Paper presented at the 2012 annual meeting of the Law \& Society Association, Honolulu, Hawaii, June 4 - 8, 2012.

Provine, Doris Marie and Meghan McDowell. 2013. SB1070: Testing the "Frustration" Hypothesis. In Latino Politics and International Relations (Lisa Magana ed.) London: Springer, in press.

Provine, Doris Marie and Monica Varsanyi. 2012. (eds.) Special Issue: Law \& Policy 34(2).

Ramakrishnan, S. Karthick, and Tom Wong. 2010. Partisanship, not Spanish: Explaining Municipal Ordinances Affecting Undocumented Immigrants. In Taking Local Control: Immigration Policy Activism in U.S. Cities and States, Monica W. Varsanyi (ed.), Stanford, CA: Stanford University Press.

Rojas-Wiesner, Martha Luz. 2007. Mujeres y Migración en la Frontera Sur de Mexico. Amérique Latine Histoire et Mémorie Les Cahiers ALHIM 14: 1-15. (2008). Personal interview, Tapachula, Mexico. (2011). Haciendo Distinctiones en la Dinámica Migratotia. Ecofrontieras 41 (enero-abril): $12-15$.

Rubio-Goldsmith, Raquel, M. Melissa McCormick, Daniel Martinez, Inez Magdalena Duarte. 2006. The "Funnel Effect" \& Recovered Bodies of Unauthorized 
Migrants Processed by the Pima County Office of the Medical Examiner, 19902005. Binational Migration Institute, Mexican American Studies \& Research Center at the University of Arizona.

Santos, Fernanda. 2012. In Arizona, Immigrants Make Plans in Shadows. New York Times, April 19. http://www.nytimes.com/2012/04/19/us/arizona-illegalimmigrants-adapt-to-a-crackdown.html (accessed April 20, 2012). 2012a. "Effort to Secure Border Crimps Commerce Along It," New York Times, December 1. http://www.nytimes.com/2012/12/02/us/effort-to-secure-bordercrimps-commerce-along-it.html?_r=0 (accessed March 4, 2013).

Sinema, Krysten. 2012. No Surprises: The Evolution of Anti-Immigrant Legislation in Arizona. In Punishing Immigrants: Policy, Politics, and Injustice. NY: New York University Press.

Singer, A., S.W. Hardwick and C.B. Brettell (eds.). 2008. Twenty-First Century Gateways: Immigrant Incorporation in Suburban America. Washington, DC: Brookings.

Spagat, Elliot, Juan Carlos Llorca, Christopher Sherman, and Brian Skoloff. 2013. Despite Progress, Many Say Border Not Secure. The Arizona Republic, February 24, A-12.

Sunnucks, Mike. 2007. Police Killing Puts Focus on Illegal Immigrant Crime. The Phoenix Business Journal, September 17. http://www.bizjournals.com/phoenix/stories/2007/09/17/daily46.html?page=all 
(accessed April 20, 2012).

United States Government Accountability Office. August 2006. GAO-06-770 Illegal Immigration: Border-Crossing Deaths Have Doubled Since 1995. United States Government Accountability Office.

Varsanyi, Monica W. 2010. Neoliberalism and Nativism: Local Anti-immigrant Policy Activism and an Emerging Politics of Scale. International Journal of Urban and Regional Research 35(2): 295-311.

Wells, Miriam J. 2004. The Grassroots Reconfiguration of U.S. Immigration Policy. International Migration Review 38(4): 1308-47.

Zaretzky, Nancy and Mark J. Rosenberg. 1998. Thinking Globally and Acting Locally: NAFTA, Globalization and the Gulf Governors' Accord. Miami, FL: Latin American and Caribbean Center, Florida International University. 


\section{ENDNOTES}

${ }^{\mathrm{i}}$ This pattern was the same throughout the 2000-mile length of the southwest border. The U.S. Government Accountability Office estimated that bordercrossing deaths across the southwest border with Mexico had doubled between 1995 and 2006 (USGAO 2006).

${ }^{\text {ii }}$ Ingrid V. Eagly has usefully outlined the provisions of this law and its tremendous power in detecting and deporting unauthorized immigrants (2011).

${ }^{i i i}$ As in many western states, propositions appear on Arizona ballots either through the referendum process, in which the legislature puts its proposals before the voters, or through the initiative process, which begins with a petition submitted by citizens.

iv The original title of the law, Fair and Legal Employment Act (FLEA) was subsequently renamed the Legal Arizona Workers Act. It became effective on January 1, 2008.

v Acuerdo para la Repatriación Ordenada, Ágil, y Segura de Migrantes Salvadoreños via Terrestre (May 2005); Acuerdo para la Repatriación Segura y Ordenada de Migrantes Centroamericanos en las Fronteras de México y Guatemala (June 2005). 